\title{
The ORIGin OF AlKRemites AND RELATED Rocks: A LU-HF, RB-SR AND SM-ND ISOTOPE STUDY
}

\author{
Nowell GM${ }^{1}$, Pearson DG ${ }^{1}$, Jacob $\mathrm{DJ}^{2}$, Spetsius $\mathbf{Z V}^{3}$, Nixon $\mathrm{PH}^{4}$ and Haggerty, $\mathrm{SE}^{5}$ \\ 1 Arthur Holmes Isotope Geology Laboratory, Durham University, UK, 2 University of Greifswald,Gremany, 3 Institute of Diamond Industry, ALROSA Co. Ltd, Yakutia, \\ 4, University of Leeds, UK, 5 Florida International University, U.SA
}

\section{INTRODUCTION \& RATIONALE}

Alkremites (spinel-garnet) and related rocks (corganites and corgaspinites) are unusual, Al-rich xenoliths found within kimberlites that appear to have equilibrated under mantle conditions (Sobolev, 1974; Nixon et al., 1978; Mazonne \& Haggerty, 1989). Although origins involving moderate/high pressure phase equilibria have been proposed (e.g. Nixon et al., 1978), several difficulties arise from these explanations, not least the reason for the initially highly aluminous magma compositions. In addition, the one alkremire garnet analysed prior to this study have a highly enriched $\mathrm{Sr}$ isotope compos ition $\left({ }^{87} \mathrm{Sr} /{ }^{86} \mathrm{Sr}>0.8\right)$ that was suggestive of a crustal origin and supported the idea that these rocks could represent the restites from subducted, melted pelitic sediments (Mazonne \& Haggerty, 1989). To further investigate these options we are carrying out a combined elemental, radiogenic and stable isotope study of alkremites and related rocks from S. Africa and Yakutia. We have undertaken a LA-ICPMS trace element and $\mathrm{Hf}-\mathrm{Nd}-\mathrm{Sr}$ isotope study of southern African (Jagersfontein, Roberts Victor \& Bellsbank) and Siberian (Udachnaya) alkremite (+corganite) xenoliths in order to further evaluate the various models proposed for their origin.

\section{METHODS \& RESULTS}

\section{ANAL YTICAL METHODS}

Most samples studied here have been previously characterised for petrography and mineral chemistry plus some whole rock geochemistry (Ponomarenko, 1975; Nixon et al., 1978; Mazzone \& Haggerty, 1989). Garnet and spinel separates were hand-picked from crushed xenoliths, to obtain optically pure splits. An aliquot of the garnet separates were taken for dissolution for trace elements and analysed by quadrupole ICP-MS at Durham University. Spinel trace elements will be analysed by laser-ablation ICPMS at the University of Greifswald. Between 30 and $100 \mathrm{mg}$ of garnet from each sample was dis solved for isotopic measurement. This corresponds to a total analyte amount of <1ng to 50ng for Hf and 10-100ng for Nd. A 2-column separation procedure was used that enables separation of $\mathrm{Hf}, \mathrm{Sr}$ and $\mathrm{Nd}$ isotopes for measurement by multi-collector plasma mass spectrometry. All samples were analysed at Durham using a ThermoFinnigan Neptune Plasma Ionisation Multicollector Mass spectrometer (PIMS). Long-term performance characteristics for this instrument are summarised by Nowell et al. (in press). For the analytical sessions used to obtain the alkremite data presented here, the average values and standard reproducibility were: J\&M ${ }^{143} \mathrm{Nd} /{ }^{144} \mathrm{Nd}=0.511104 \pm 11, \quad 2 \mathrm{SD} \quad \mathrm{n}=17 ; \quad \mathrm{JMC}-475$ ${ }^{176} \mathrm{Hf} /{ }^{177} \mathrm{Hf}=0.2821545 \pm 9,2 \mathrm{SD} n=19$. Data are normalized to accepted values for JMC 475 of 0.282160 (Nowell et al., 1998) and J\&M of 0.511110 (Nowell et al, in press).

\section{GARNET CHEMISTRY}

Garnets from the S. African alkremites are pyropealmandine-grossular solid solutions with low $\mathrm{Cr}$. In contrast, Udachnaya Alkremites can be divided into two groups on the basis of their garnet compositions (Ponomarenko \& Leskova, 1980). One group has garnet compositions similar to $\mathrm{S}$. African alkremites, with relatively high in $\mathrm{MgO}$ and $\mathrm{CaO}$ contents above 4 wt $\%$. The second group has garnets that are very pyrope rich (>22 wt $\% \mathrm{MgO}$ ) and < 4wt\% $\mathrm{CaO}$. Garnets from southern African Alkremites only rarely approach these pyrope-rich compositions. Despite this garnets from Bellsbank alkremites can be divided into $\mathrm{Mg}$-rich and Mg-poor groups. One sample from Robert's Victor studied by Nixon et al (1978) had elevated pyrope and an additional sample in our suite from Robert's Victor also was pyrope-rich. This garnet signature is generally accompanied by Cr-rich spinel compositions (Ponomarenko \& Leskova, 1980).

\section{TRA CE ELEMENTS}

Garnets REE patterns appear to form 3 general groups which vary in LREE /MREE but are most distinctive in their MREE/HREE fractionation (Figure 1). The high 
pyrope garnets from Udachnaya alkremites have extreme HREE/MREE enrichment $\left(\mathrm{Dy}_{\mathrm{n}} / \mathrm{Lu}_{\mathrm{n}}\right.$ values $<<1)$. One exceptional sample from Udachnaya has a $\mathrm{Lu}$ content of $6.6 \mathrm{ppm}$ and ${ }^{176} \mathrm{Lu} /{ }^{177} \mathrm{Hf}$ of 25.7 . This signature is accompanied by low ${ }^{147} \mathrm{Sm} /{ }^{144} \mathrm{Nd}(0.063)$. In general, the shape of the garnet REE pattern, and its $\mathrm{Lu} / \mathrm{Hf}$ ratio correlates with the pyrope content of the garnet.

${ }^{176} \mathrm{Lu} /{ }^{177} \mathrm{Hf}$ in S. African alkremite garnets in general are much less fractionated and vary from 0.006 to 0.098. ${ }^{147} \mathrm{Sm} /{ }^{144} \mathrm{Nd}$ varies from 0.094 to $0.7 .{ }^{87} \mathrm{Rb} /{ }^{86} \mathrm{Sr}$ ratios in garnets are very variable (0.058 to 1.33$)$.

Some of the low $\mathrm{Mg}$ garnets have very anomalous $\mathrm{Ba}$ contents (up to $107 \mathrm{ppm}$ ) that are accompanied by very high $\mathrm{Zr}$ contents (up to 700ppm). Laser ablation studies of trace element zonation are in progress to ascertain whether these anomalous concentrations are simply the product of kimberlite-related metasomatism.

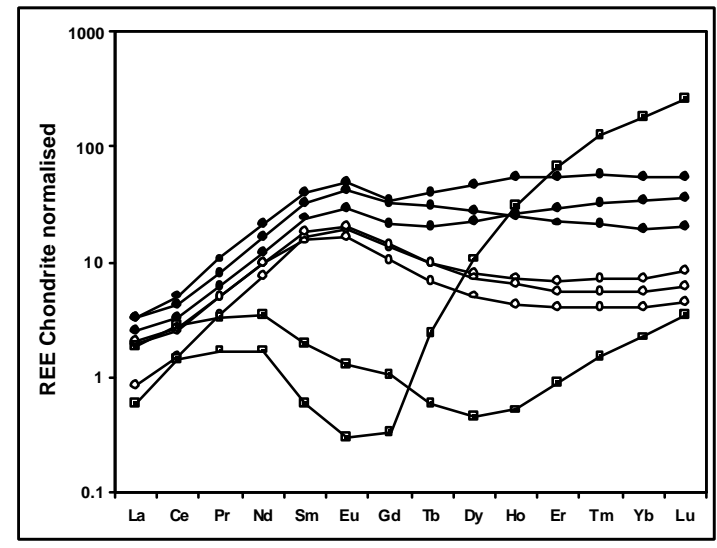

Figure 1: Chondrite-normalised REE patterns for alkremite garnets from Bellsbank (Open and closed circles) and Udachnaya (Closed squares).

\section{INITIAL LU-HF AND SM-ND RESULTS}

At present, our isotopic database is dominated by samples from Bellsbank and 2 samples from Udachnaya. Samples from Jagersfontein and Roberts Victor will also be analysed. The six samples from Bellsbank can be divided into two distinct isotopic groups each with a restricted range of $\mathrm{Nd}$ and $\mathrm{Hf}$ isotopic compositions. These two Bellsbank groups correlate with the groups identified from major element and REE compositions. Eruption-age corrected initial epsilon $\mathrm{Nd}$ values for the two groups are: 0.5 to 0.85 and 1.3 to 2.6. The two groups are more distinct in terms of their Hf isotopic compositions, one group with
EHfi values ranging from 2.6 to 10 and the other group having a range from 47 to 66 . These compositions are distinct from that of the host kimberlite (Nowell et al., in press) and hence do not simply reflect host rock contamination/metasomatism.

The Udachnaya alkremite garnets have very distinctive initial $\mathrm{Nd}$ and $\mathrm{Hf}$ isotopic in comparison to the Bellsbank alkremites. They are characterised by enriched epsilon $\mathrm{Nd}$ values (-7.5 to -11$)$ and extremely radiogenic epsilon $\mathrm{Hf}$ values (145 to 24960). This initial epsilon Hf value of 24960 is the most radiogenic composition ever measured for a mantle-derived mineral or rock by an order of magnitude.

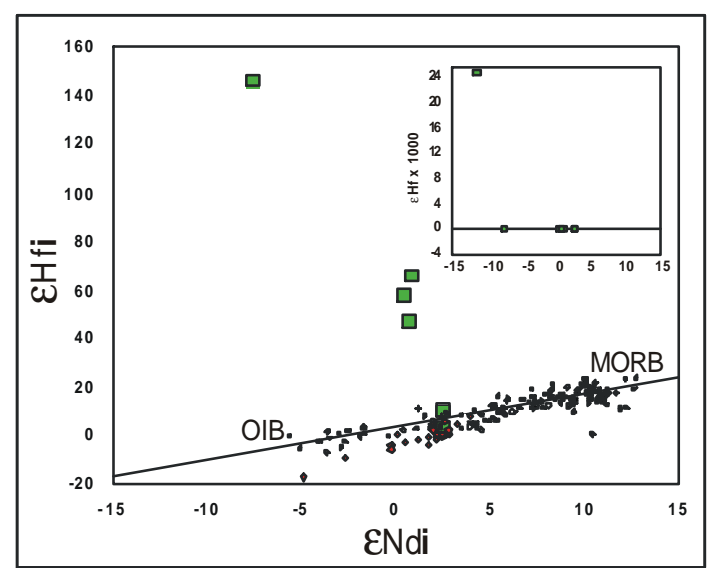

Figure 2: Initial $\varepsilon \mathrm{Hf}_{\mathrm{i}}$ versus $\boldsymbol{E N d}_{\mathrm{i}}$ for alkremite garnets (large grey squares). Small data points delineate the MORB-OIB field. Inclined line represents the terrestrial array. Inset is expanded to show the extreme sample from Udachnaya with $\mathcal{E} \mathrm{Hf}_{\mathrm{i}}$ of 24960 .

\section{DISCUSSION}

The Lu-Hf and Sm-Nd isotope systematics of the alkremites studied are highly complex. As such they are very difficult to interpret in terms of simple single-stage petrogenetic models involving subduction of crustal material or high-pressure cumulates from fractionated mantle magmas. The highly variable nonsystematic TDM Nd and Hf model ages indicate decoupling between parent-daughter and isotopic compositions, i.e. a multi-stage history.

Samples showing highly radiogenic Hf isotopic compositions must have experienced long-term evolution with elevated Lu/Hf ratios. This could have occurred via either partial melting of crustal material during subduction leaving a refractory residue 
(Mazzone \& Haggerty, 1989). Such restites would also acquire high $\mathrm{Sm} / \mathrm{Nd}$ relative to their precursors and hence with time could evolve to the observed Hf-Nd isotopic compositions. However, high-pressure cumulates from mantle-derived magma would also share these parent-daughter isotope characteristics and hence our current data cannot distinguish between these two alternatives.

Although our current data does not allow firm statements to be made concerning the origin of the various alkremite suites, the extreme Lu-Hf fractionation shown by the two Udachnaya alkremite garnets provide precise constraints on the timing of their formation. The TDM model ages for the two Udachnaya samples are $1795 \pm 35 \mathrm{Myr} \quad(2 \sigma)$ and $2014 \pm 104 \mathrm{Myr}(2 \sigma)$. In addition, these two samples yield a $\mathrm{Lu}-\mathrm{Hf}$ isochron age of $1794 \pm 35 \mathrm{Ma}$, within error of the most precise TDM age. These ages do have geological significance in terms of the tectonic evolution of the Siberian craton. Recent compilation of crustal isotopic ages show that the craton experienced major amalgamation events in the late PalaeoProterozoic, starting at $2 \mathrm{Ga}$ and terminating with a major collisional orogen at $1.8 \mathrm{Ga}$ ago (Rosen et al., 2002). The alkremite ages appear to faithfully record the assembly of the Archean tectonic provinces that form the Siberian craton.

\section{REFERENCES}

Nixon, P.H., Chapman, N.A., Gurney, J.J., 1978. PyropeSpinel (Alkremite) Xenoliths from Kimberlite. Contrib. Mineral. Petrol. 65: 341-346.

Nowell, G. M., Kempton, P. D., S.R.Noble, Fitton, J. G., A.D.Saunders, Mahoney, J. J. \& Taylor, R. N. 1998. High precision $\mathrm{Hf}$ isotope measurements of MORB and OIB by thermal ionisation mass spectrometry: Insights into the depleted mantle. Chemical Geology 149, 211-233.

Nowell, G.M., Pearson, D.G., Ottley, CJ., Schwieters, I, Dowall, D. P. (in press). Long-term performance of Plasma Ionisation Multi-collector Mass Spectrometer (PIMMS): The ThermoFinnigan Neptune. In G. Holland and S.D. Tanner (Eds). Plasma Source Mass Spectrometry. Special Publication of the Royal Society of Chemistry.

Pearson, DG., Carlson, R.W., Shirey, S.B., Boyd, F.R., Nixon, P.H., 1995. Stabilization of Archean Lithospheric Mantle: A Re-Os Isotope Study of Peridotite Xenoliths From the Kaapvaal Craton. Earth and Planetary Science Letters, 134(3-4): 341-357.

Ponomarenko, AI., 1975. Alkremite - a new variety of aluminuous hyperbasite xenoliths from the kimberlites of
Udachnaya pipe Doklady Akad Nauk US.S.R., 225: No.4.

Ponomarenko, AI., Leskova N.V., 1980. Peculiarities of chemical composition of minerals of alkremites from kimberlite pipe "Udachnaya". Dokl. Akad. Nauk SSSR 252(3), 707-711 (in Russian).

Rosen, O.M., Serenko, VP., Spetsius, ZV., Manakov, A.V., Zinchuk, N.N. 2002. Yakutian Kimberlite province: Position in the structure of the Siberian craton and composition of the upper and lower crust. Russian Geology and Geophysics, 43(1): 124.

Contact: G.M. Nowell, Arthur Holmes Isotope Geology Laboratory, Department of Geological Sciences, Durham University, South Road, Durham, DH1 3LE, UK, E-mail: gm.nowall@durham.ac.uk 